Research article

urn:lsid:zoobank.org:pub:F682863D-C20B-4DE7-97B9-4EB0D4E20649

\title{
New Chummidae (Araneae): quadrupling the size of the clade
}

\author{
Rudy JOCQUÉ ${ }^{1, *} \&$ Mark ALDERWEIRELDT ${ }^{2}$ \\ ${ }^{1}$ Royal Museum for Central Africa, Steenweg op Leuven 13, B-3080 Tervuren, Belgium. \\ ${ }^{2}$ University Ghent, Terrestrial Ecology Unit, K.L. Ledeganckstraat 35, B-9000 Gent, Belgium. \\ *Corresponding author: rudy.jocque@africamuseum.be \\ ${ }^{2}$ Email: malderweireldt@hotmail.com \\ ${ }^{1}$ urn:lsid:zoobank.org:author:CF15016C-8CD1-4C9D-9021-44CA7DC7A5D5 \\ ${ }^{2}$ urn:lsid:zoobank.org:author:CE20F264-3E66-4481-86A9-06ACCD1941AE
}

\begin{abstract}
The recently described family Chummidae, now the sister clade of Macrobuninae, so far only known from two South African species, is extended with seven new species, six from the southern part of South Africa and one from Lesotho: Chumma bicolor sp. nov. (ㅇ), C. foliata sp. nov. ( $\oint^{\lambda}+$ ),

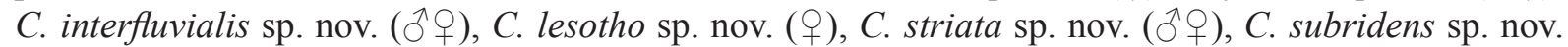
( $\hat{\partial}+$ ) and C. tsitsikamma sp. nov. $\hat{\delta}$. A key to the species is provided. Although Chumma is part of a clade containing the Macrobuninae, it is argued that the family name Chummidae should remain valid.
\end{abstract}

Keywords. Chumminae, Lesotho, Macrobuninae, South Africa, temperate distribution.

Jocqué R. \& Alderweireldt M. 2018. New Chummidae (Araneae): quadrupling the size of the clade. European Journal of Taxonomy 412: 1-25. https://doi.org/10.5852/ejt.2018.412

\section{Introduction}

Whereas the creation of new families is rather commonplace (Bond et al. 2012; Polotow et al. 2015; Miller et al. 2010), the finding of a new spider family on newly collected material has become a very rare event. The monospecific Trogloraptoridae Griswold, Audisio \& Ledford, 2012 is such a family and the last one that was described on newly collected specimens (Griswold et al. 2012). More than ten years earlier, another new family-level spider taxon, Chummidae Jocqué, 2001, was described on new material of two species, Chumma inquieta Jocqué, 2001 and C. gastroperforata Jocqué, 2001, from the Cape Region in South Africa (Jocqué 2001). The most remarkable character of this taxon is the presence of a field with spines on the dorsal abdominal scutum. The family, therefore, received the vernacular name 'spiny backed spiders' (Jocqué \& Dippenaar-Schoeman 2007). Since then, many more specimens were collected. These proved to contain seven new species, which are described here. With this study we quadruple the size of the clade since it will now contain nine species. A key to the species is provided.

\section{Material and methods}

Specimens were observed, drawn and measured with a Nikon SMZ 1270 and a Leica M10 stereo microscope. Details of the female genitalia and male palps were observed with a Leica MZ 16 stereo microscope. Measurements and photographs of the habitus, details of mouthparts, detached male palps 
and female genitalia were taken with a Leica MZ16 using the LAS automontage software (v. 3.8). The female genitalia were dissected and cleared with methylsalicylate.

Types are deposited in the Royal Museum for Central Africa, Tervuren, Belgium (MRAC) and the National Collection of Arachnida, Pretoria, South Africa (NCA).

All measurements are in mm. All palp illustrations are from left palps.

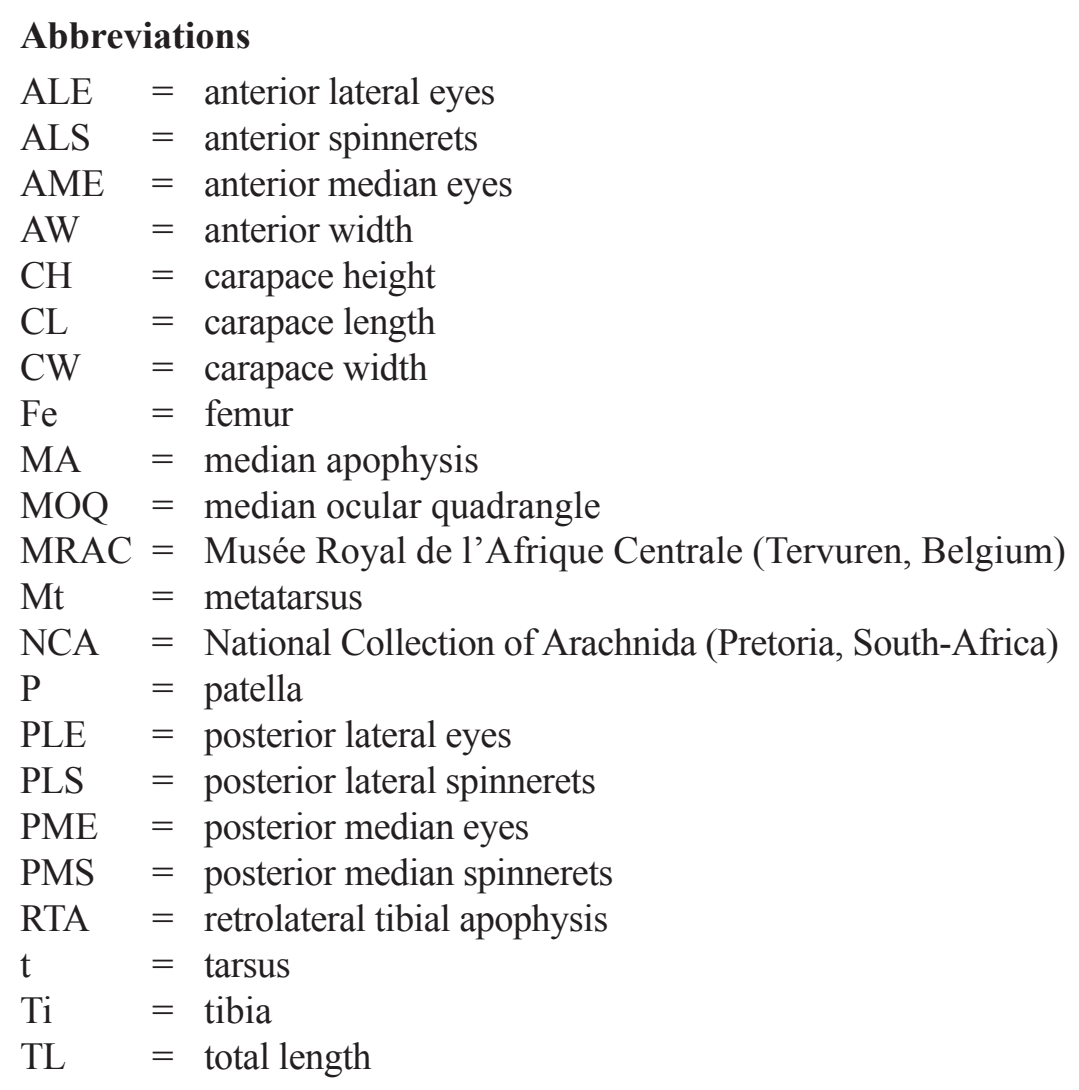

\section{Results}

Class Arachnida Cuvier, 1812

Order Araneae Clerck, 1757

Family Chummidae Jocqué, 2001

Genus Chumma Jocqué, 2001

\section{Key to the species of Chumma}

Species included:

C. bicolor sp. nov. ㅇ

C. foliata sp. nov. $\stackrel{1}{0}$ ?

C. gastroperforata Jocqué, 2001 ふึ우

C. inquieta Jocqué, 2001 Ð우

C. interfluvialis sp. nov. ${ }^{\circledR}+9$

C. lesotho sp. nov. +9

C. striata sp. nov. ํㅜㅇㅜ

C. subridens sp. nov. $\widehat{\supset}$ 우

C. tsitsikamma sp. nov. $\widehat{\widehat{\sigma}}$ 


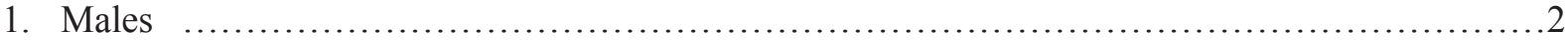

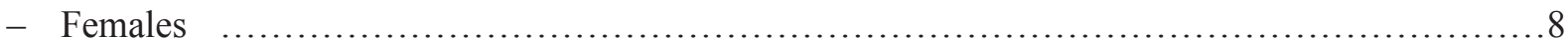

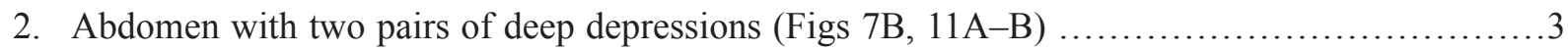

- Abdomen without deep depressions (Fig. 3A) ...............................................

3. Pointed prong of dorsal RTA separate from truncated part and more than half as long (Fig. 11C-E) C. tsitsikamma sp. nov.

- Pointed prong of dorsal RTA inserted on truncated part and much shorter .......................4

4. Pointed prong of dorsal RTA inserted near base of truncated part; palpal tibia longer than wide (Jocqué 2001: fig. 10b-c) ................................... gastroperforata Jocqué, 2001

- Pointed prong of dorsal RTA inserted near tip of truncated part; palpal tibia as wide as long (Fig. 7C-E)

C. striata sp. nov.

5. Tegulum with long slender and short sharp processes pointing forward; dorsal part of RTA broad, foliate (Figs 2B, 3C-D) C. foliata sp. nov.

- Tegulum without pointed processes; dorsal part of RTA smaller

6. Cymbium with retrolateral posterior extension and prolateral basal knob (Jocqué 2001: fig. 6a-c) C. inquieta Jocqué, 2001

- Cymbium without prolateral knob .7

7. P III with four prolateral spines; embolus short, not sinuous (Figs 8C, 9C) ...C. subridens sp. nov.

- P III without spines; embolus long, sinuous (Figs 4C, 5C) C. interfluvialis sp. nov.

8. Epigyne with two large openings separated by broad septum (Fig. 3E); spermathecae oval, slightly more than their shortest diameter apart (Fig. 3F)

C. foliata sp. nov.

- Epigyne never with large openings; spermathecae not so far apart .9

9. Dorsum of abdomen with contrasting dark lateral patches (Fig. 1A-B); epigyne on either side with group of setae converging toward the centre (Fig. 2A); copulatory ducts each with large anterior atrium (Fig. 1E) C. bicolor sp. nov.

- Dorsum of abdomen uniform; epigyne without groups of converging setae; copulatory ducts without anterior atrium .10

10. Epigyne with dark oval or triangular septum in the middle near posterior margin (Figs 4E, 6C, 7F)

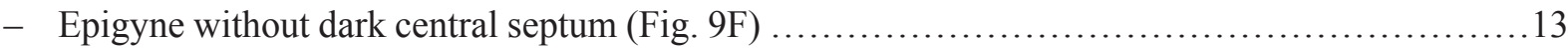

11. Scutum covering $2 / 3$ of dorsum (Fig 7A); white spots behind sockets of dorsal abdominal setae absent; spermathecae subcircular, $3 / 4$ of their diameter apart (Fig. 7G).

C. striata sp. nov.

- Scutum covering at least $3 / 4$ of dorsum; white spots behind sockets of dorsal abdominal setae large; spermathecae closer

12. Spermathecae subglobular; with small anterior protuberance (Fig. 6D)

C. lesotho sp. nov.

- Spermathecae oval; without anterior protuberance (Fig. 4F) C. interfluvialis sp. nov.

13. Posterior margin of epigyne deeply incurved leaving membranous area (Jocqué 2001: fig. 7a) ...... C. inquieta Jocqué, 2001

- Posterior rim of epigyne not deeply incurved 
14. Posterior margin of epigyne with small indentation; with two large dark areas converging towards the back (Jocqué 2001: fig. 11a); profile of spermathecae in dorsal view almost quadrangular with concave sides (Fig. 7H) ................. gastroperforata Jocqué, 2001

- Posterior dark margin of epigyne slightly procurved without indentation; with two widely separated, small dark areas (Figs 8E, 9F); profile of spermathecae in dorsal view oval, in front with short straight stretch (Fig. 9G) C. subridens sp. nov.

Chumma bicolor sp. nov.

urn:1sid:zoobank.org:act:5AA2B187-E836-451B-9A88-2707AA478AE7

Figs 1A-E, 2A, 12

\section{Diagnosis}

Chumma bicolor sp. nov. differs from related species by the contrasting dark areas on the abdomen; the spermathecae are provided with a large ventral atrium in front.

\section{Etymology}

The specific epithet is an adjective obviously referring to the contrasting colouration of the abdomen.

\section{Material examined}

\section{Holotype}

SOUTH AFRICA: + , Western Cape Province, Goukamma, $34^{\circ} 03.478^{\prime} \mathrm{S}, 22^{\circ} 56.315^{\prime} \mathrm{E}$, beating shrubs on path near forest lodge, 31 Jan. 2014, R. Jocqué and E. Tybaert leg. (MRAC 244719).

\section{Paratype}

SOUTH AFRICA: $q$, same data as for holotype (MRAC 244720).

\section{Note}

On 2 February 2017, shrub beating was carried out during three hours at the type locality in search of males of the species. No extra specimens were found.

\section{Description}

\section{Female}

Body MEASUREMENTS. TL 3.17, CL 1.27, CW 1.10, CH 0.53.

CARAPACE. Pale yellow with orange patches (Fig. 1A-C).

Aвdomen (Fig. 1B). Pale, with yellow orange scutum with reddish apodemes; posterior half with dark patch on either side; venter, sternum and spinnerets pale yellow. Entirely covered with short spines, each socket just in front of pale spot.

Eyes. AME: 0.20; ALE: 0.30; AME-AME: 0.07; AME-ALE: 0.07; PME: 0.20: PLE: 0.30; PME-PME: 0.20; PME-PLE: 0.17 . Clypeus 0.23 or 0.77 times width of ALE.

STERnUm. Length 1.97, width: 1.77.

Legs. One prolateral spine on femur I. 
LEG MEASUREMENTS.

\begin{tabular}{ccccccc}
\hline & Fe & P & Ti & Mt & t & Total \\
\hline I & 1.07 & 0.40 & 1.00 & 0.83 & 0.23 & 3.53 \\
II & 0.97 & 0.37 & 0.77 & 0.67 & 0.50 & 3.27 \\
III & 0.77 & 0.37 & 0.67 & 0.73 & 0.40 & 2.93 \\
IV & 1.20 & 0.40 & 0.90 & 1.07 & 0.53 & 4.10 \\
\hline
\end{tabular}
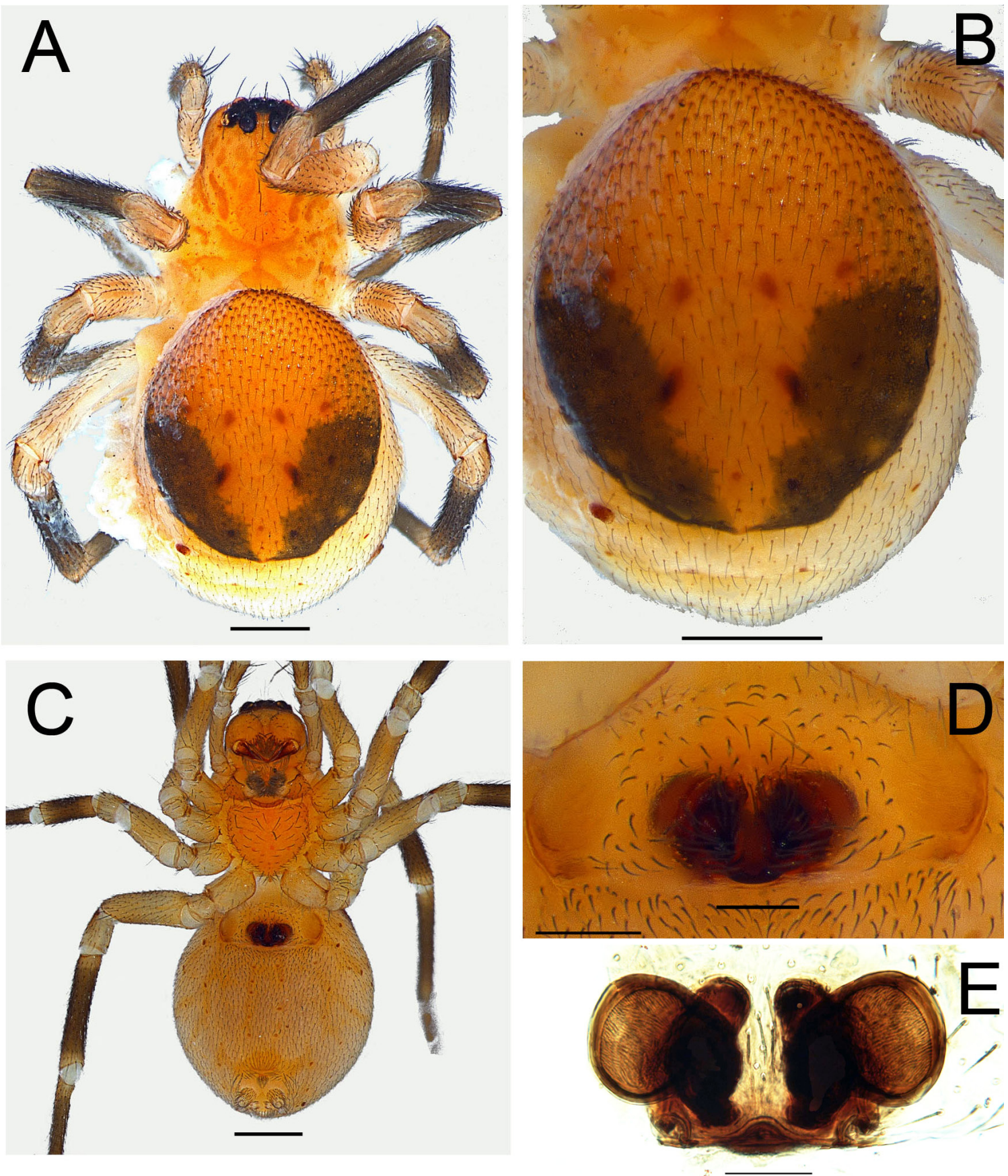

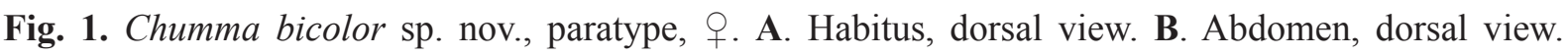
C. Habitus, ventral view. D. Epigyne, ventral view. E. Epigyne, cleared, dorsal view. Scale bars: A-C = $0.5 \mathrm{~mm}$; D-E $=0.1 \mathrm{~mm}$. 
EPIGYNe (Figs 1D-E, 2A). Dark area with narrow transverse plate near posterior rim; central dark swelling with posterior extension in longitudinal axis; spermathecae large, rounded, with large ventral atrium in front near centre.

\section{Male}

Unknown.

\section{Distribution}

Only known from the type locality in the Western Cape Province in South Africa (Fig. 12).

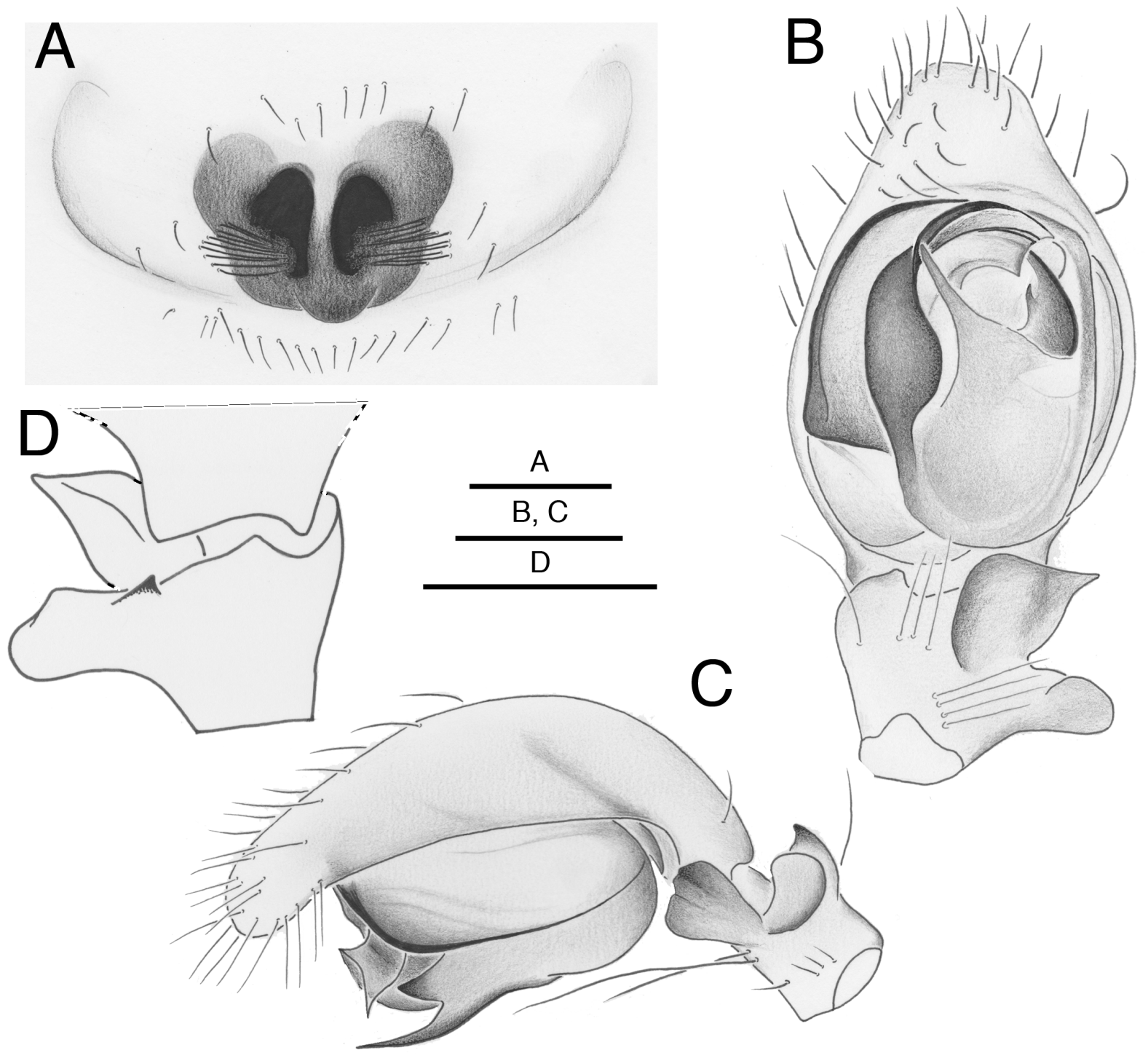

Fig. 2. A. Chumma bicolor sp. nov., paratype, $q$, epigyne, ventral view. - B-D. Chumma foliata sp. nov., holotype, §. B. Palp, ventral view. C. As preceding, retrolateral view. D. Palpal tibia, dorsal view. Scale bars: $0.2 \mathrm{~mm}$. 
Chumma foliata sp. nov. urn:lsid:zoobank.org:act:09349F06-E7C8-42C2-B073-54F7340B1331

Figs 2B-D, 3A-F, 12

\section{Diagnosis}

Males of $C$. foliata sp. nov. are recognized by the palpal tibia with a small pointed dorsal tooth and the large foliate dorsal part of the RTA and the long, slender, anterior projection of the tegulum; the female is recognized by the epigyne with two large copulatory openings in the centre.

\section{Etymology}

The specific epithet refers to the foliate upper RTA.

\section{Material examined}

\section{Holotype}

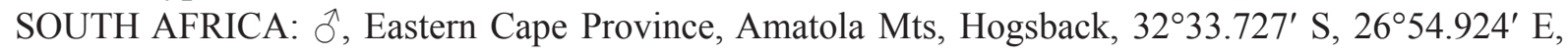
$1460 \mathrm{~m}$ a.s.l., grass tussocks, alpine grassland, 28 Nov. 2013, C. Haddad and J. Neethling leg. (NCA 2015/4654).

\section{Other material}

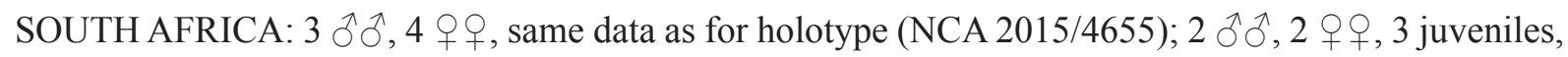
South Africa, Eastern Cape Province, Amatola mountains, Hogsback, Amatola Forestry Company, $32^{\circ} 37.671^{\prime} \mathrm{S}, 26^{\circ} 58.311^{\prime} \mathrm{E}, 1210 \mathrm{~m}$ a.s.1., grass tussocks in Fynbos, 28 Nov. 2013, C. Haddad leg. (NCA

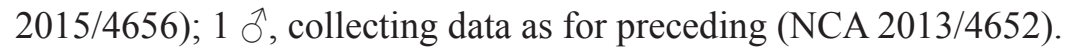

\section{Description}

\section{Male}

BODY MEASUREMENTS. TL 2.33, CL 1.00, CW 0.83, CH 0.57.

Carapace. Pale yellow with some faint darker patches. Chelicerae, sternum and legs uniform yellow (Fig. 3A).

AвDomen. Dorsum with poorly sclerotized marbled scutum with few long supple setae in front, sockets on pale circles, apodemes slightly impressed; sides and venter pale with few apodemes in two rows; transverse group of setae in front of spinnerets.

Eyes. AME: 0.17; ALE: 0.20; AME-AME: 0.07; AME-ALE: 0.03; PME: 0.20: PLE: 0.20; PME-PME: 0.17; PME-PLE: 0.10. Clypeus 0.20 or 1.00 times width of ALE.

STERnUM. Length 1.63, width 1.57, almost as wide as long.

LEGs. Anterior pairs of tarsi slightly curved, not fusiform. All Fe with one dorsal spine, Fe I with one prolateral spine.

LEG MEASUREMENTS.

\begin{tabular}{ccccccc}
\hline & $\mathbf{F e}$ & $\mathbf{P}$ & $\mathbf{T i}$ & $\mathbf{M t}$ & $\mathbf{t}$ & Total \\
\hline I & 1.03 & 0.33 & 1.00 & 0.83 & 0.47 & 3.67 \\
II & 0.87 & 0.30 & 0.80 & 0.73 & 0.47 & 3.17 \\
III & 0.73 & 0.30 & 0.57 & 0.73 & 0.40 & 2.73 \\
IV & 1.00 & 0.83 & 0.33 & 1.00 & 0.50 & 3.67 \\
\hline
\end{tabular}



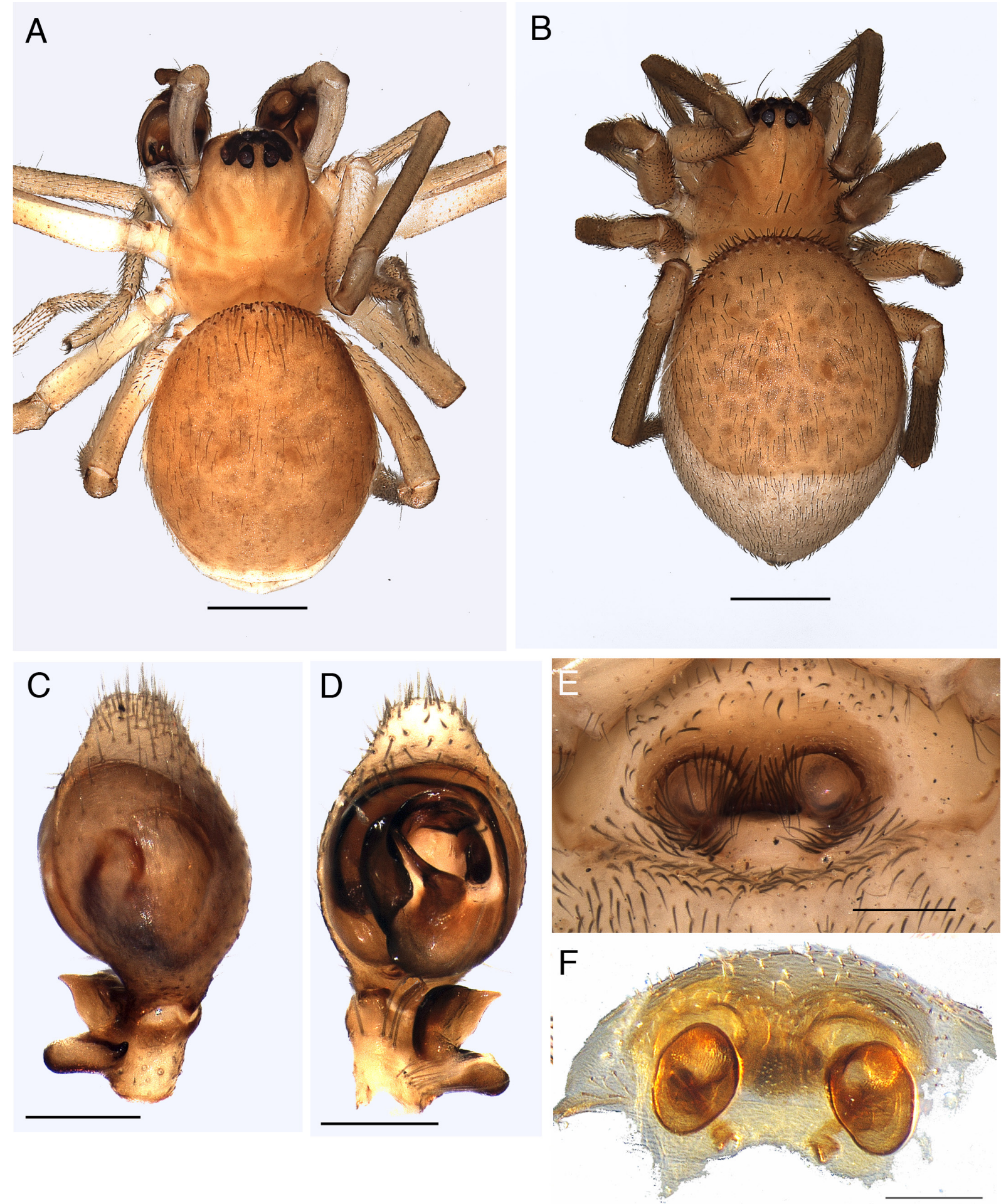

Fig. 3. Chumma foliata sp. nov. A, $\mathbf{C}-\mathbf{D}=$ holotype, $\widehat{\jmath}$. B, $\mathbf{E}-\mathbf{F}=$ paratype, $\uparrow$. A. Habitus, dorsal view. B. Habitus, dorsal view. C. Palp, dorsal view. D. As preceding, ventral view. E. Epigyne, ventral view. F. Epigyne, cleared, dorsal view. Scale bars: $\mathrm{A}-\mathrm{B}=0.5 \mathrm{~mm}$; $-\mathrm{F}=0.2 \mathrm{~mm}$. 
PALP (Figs 2B-D, 3C-D). Tibia with large RTA, dorsal one with large rounded flap and short curved tip, ventral one short, massive, truncated at tip, with concave ventral sides; cymbium with triangular extension at retrolateral base, fitting in concavity between RTA; tegulum with slender, sharp ventral prong; embolus short, broad, strongly curved and truncated.

\section{Female}

Body MEASUREMENTS. TL 2.83, CL 1.07, CW 0.97, CH 0.50.

Colour AND PATterns. Very similar to male (Fig. 3B).

Eyes. AME: 0.17; ALE: 0.23; AME-AME: 0.07; AME-ALE: 0.07; PME: 0.20; PLE: 0.23; PME-PME: 0.23; PME-PLE: 0.13. Clypeus 0.27 or 1.17 times width of ALE.

STERnUM. Length 1.90, width 1.80, almost as wide as long.

LEG MEASUREMENTS:

\begin{tabular}{ccccccc}
\hline & Fe & $\mathbf{P}$ & $\mathbf{T i}$ & $\mathbf{M t}$ & $\mathbf{t}$ & Total \\
\hline I & 1.07 & 0.40 & 1.00 & 0.83 & 0.50 & 3.80 \\
II & 0.97 & 0.37 & 0.77 & 0.67 & 0.43 & 3.20 \\
III & 0.77 & 0.33 & 0.57 & 0.67 & 0.37 & 2.70 \\
IV & 1.17 & 0.40 & 0.90 & 1.03 & 0.47 & 3.97 \\
\hline
\end{tabular}

EPIGYNE (Fig. 3E-F). With two large, rounded copulatory openings leading directly into the spermathecae, separated by broad scape, delimiting a membranous area in front of the epigastric fold.

\section{Distribution}

Known from the Amatola Mts in the Eastern Cape Province in South Africa (Fig. 12).

Chumma interfluvialis sp. nov. urn:1sid:zoobank.org:act:06C2288D-19D5-496B-99CF-0733D34FD871

Figs 4A-F, 5A-D, 12

\section{Diagnosis}

Males of C. interfluvialis sp. nov. are recognized by the presence of prolateral spines on P III, the palpal tibia with dorsal apophysis with rounded tip and foliate ventral apophysis with dorsal tooth, and the sinuous embolus; the female is characterized by the epigyne with a dark roughly oval central area near the posterior margin.

\section{Etymology}

The specific epithet refers to type locality 'Tussen-die-Riviere' which means 'between the rivers', 'interfluvialis' in Latin.

\section{Material examined}

\section{Holotype}

SOUTH AFRICA: $\widehat{\jmath}$, Free State Province, Tussen-die-Riviere Nature Reserve, Bank of Orange river, $30^{\circ} 29.192^{\prime}$ S, $26^{\circ} 10.557^{\prime}$ E, 1270 m a.s.l., dense Acacia karroo woodland, sifting leaf litter, 15 Oct. 2008, C. Haddad and L. Lotz leg. (NCA 2015/4657).

\section{Paratypes}

SOUTH AFRICA: $2 \hat{\jmath} \hat{o}, 2$ 우, 3 juveniles, same collecting data as for holotype (NCA 2015/4658). 


\section{Description}

\section{Male}

Body MEASUREMENTS. TL 2.83, CL 1.17, CW 0.87, CH 0.47.

CARAPACE. Dark yellow, with medium brown radiating striae (Fig. 4A). Chelicerae, legs and sternum uniform yellow.

ABDomen. Dorsum covered entirely with brown scutum. Anterior setae spine-shaped, in sockets in front of small pale circles, these smaller further backwards, absent from half way length; sides and venter pale, provided with dense cover of setae and rows of apodemes.

Eyes. AME: 0.17; ALE: 0.30; AME-AME: 0.03; AME-ALE: 0.03; PME: 0.20; PLE: 0.20; PME-PME: 0.20; PME-PLE: 0.13. Clypeus 0.17 or 0.63 times width of ALE.

STERNUM. Length 1.83, width 1.63.

Legs. Tarsi I and II fusiform. Fe I with one dorsal and one prolateral spine, Fe II with one dorsal spine; $\mathrm{Pa}$ III with one proximal spine and a distal row of three spines.

LEG MEASUREMENTS.

\begin{tabular}{ccccccc}
\hline & $\mathbf{F e}$ & $\mathbf{P}$ & $\mathbf{T i}$ & $\mathbf{M t}$ & $\mathbf{t}$ & Total \\
\hline I & 0,93 & 0,33 & 0,80 & 0,67 & 0,50 & 3,23 \\
II & 0,77 & 0,33 & 0,67 & 0,57 & 0,40 & 2,73 \\
III & 0,60 & 0,20 & 0,33 & 0,50 & 0,30 & 1,93 \\
IV & 0,93 & 0,37 & 0,73 & 0,80 & 0,43 & 3,27 \\
\hline
\end{tabular}

Palp (Figs 4C-D, 5A-C). Tibia with many long setae, with two apophyses: dorsal one with flat twisted base, rounded dorsal prong and sharp ventral prong; ventral one short with short sharp tip pointing upwards; embolus central on distal part of tegulum, flat, slightly sinuous, MA with elongate membranous prong.

\section{Female}

Body MEASUREMENTS. TL 2.90, CL 1.17, CW 0.97, CH 0.43.

PATterns AND COlour. Very similar to male (Fig. 4B). Abdominal scutum shorter and posterior margin concave; fewer apodemes.

Eyes. AME: 0.20; ALE: 0.27; AME-AME: 0.07; AME-ALE: 0.03; PME: 0.23: PLE: 0.30; PME-PME: 0.20; PME-PLE: 0.10 . Clypeus 0.17 or 0.57 times width of ALE.

Sternum. Length 1.67 , width 1.57 , almost as wide as long.

LeGs. Anterior pairs of tarsi slightly curved but not fusiform. Fe I with one dorsal and one prolateral spine, Fe II with one dorsal spine; no spines on Pa III.

LEG MEASUREMENTS.

\begin{tabular}{ccccccc}
\hline & Fe & P & Ti & Mt & t & Total \\
\hline I & 0.83 & 0.33 & 0.80 & 0.63 & 0.43 & 3.03 \\
II & 0.77 & 0.33 & 0.67 & 0.57 & 0.40 & 2.73 \\
III & 0.67 & 0.33 & 0.40 & 0.57 & 0.30 & 2.27 \\
IV & 0.87 & 0.33 & 0.77 & 0.90 & 0.37 & 3.23 \\
\hline
\end{tabular}



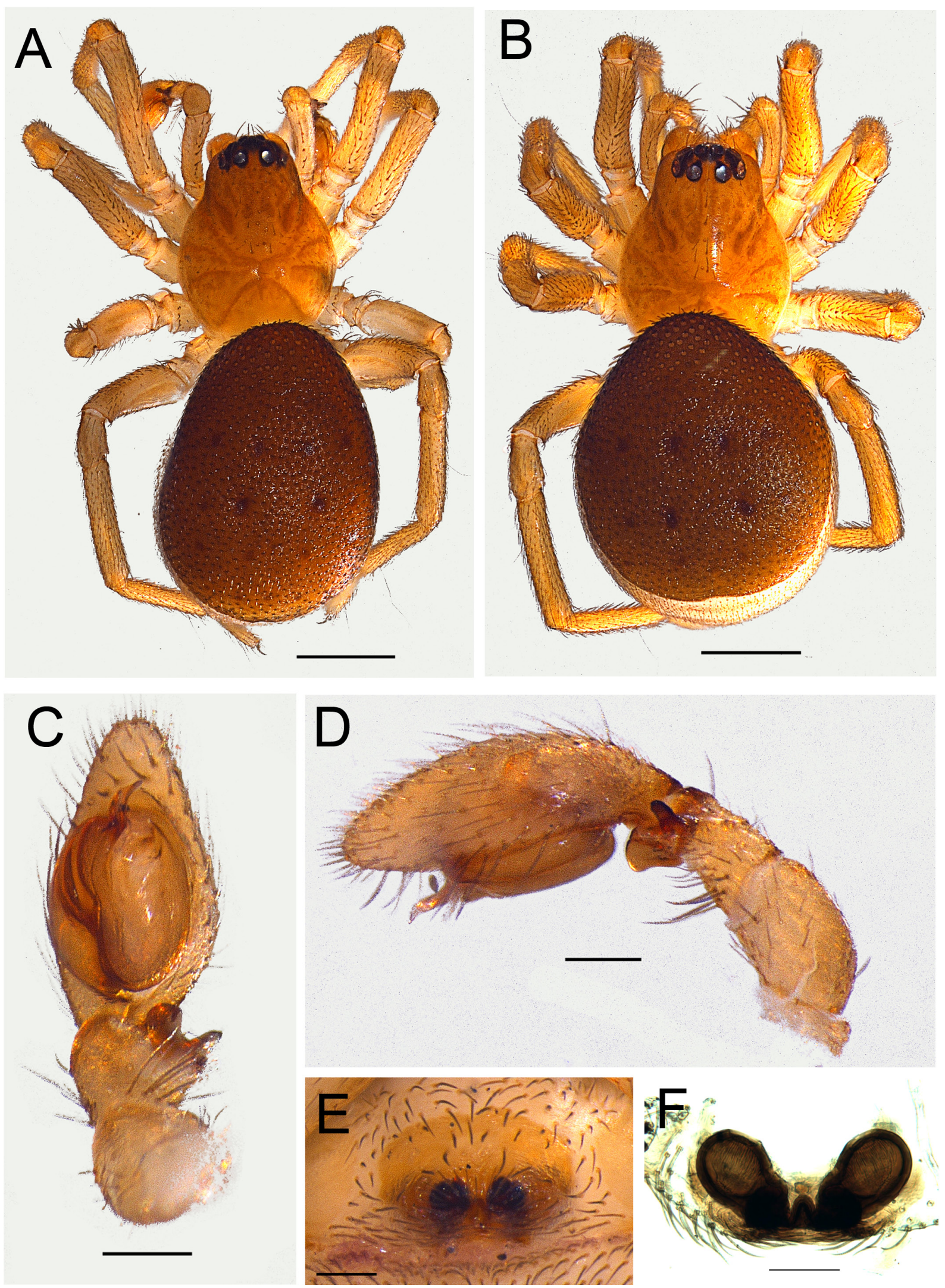

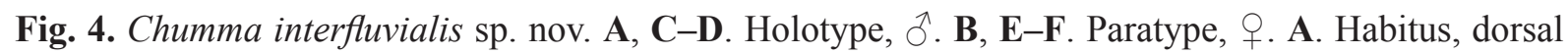
view. B. Habitus, dorsal view. C. Palp, ventral view. D. As preceding, retrolateral view. E. Epigyne, ventral view. F. Epigyne, cleared, dorsal view. Scale bars: A-B $=0.5 \mathrm{~mm}$; C-F $=0.2 \mathrm{~mm}$. 
EpIGYNe (Figs 4E-F, 5D). Oval sclerified area with two black spots, separated by small, dark recurved ridge; with central rounded tip, dark spermathecae visible in transparency; spermathecae large, oval and converging towards back.

\section{Distribution}

Known from the Tussen-die-Riviere Nature Reserve in the Free State in South Africa (Fig. 12).
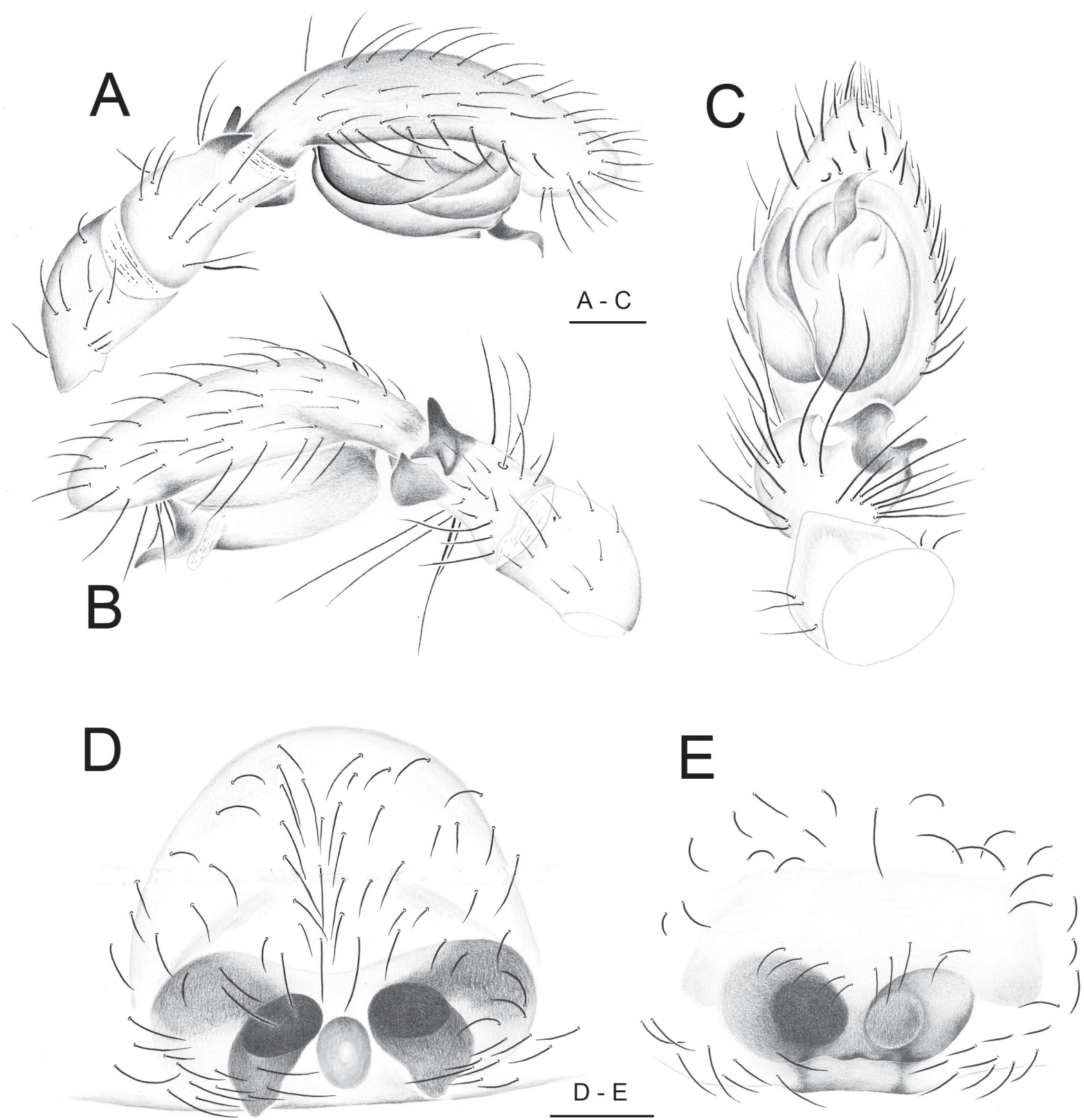

Fig. 5. A-D. Chumma interfluvialis sp. nov. A-C. Holotype, Ô. A. Palp, prolateral view. B. As preceding, retrolateral view. C. As preceding, ventral view. D. Paratype, $q$, epigyne, ventral view. - E. Chumma lesotho sp. nov., holotype,, , epigyne, ventral view. Scale bars: $0.2 \mathrm{~mm}$. 
Chumma lesotho sp. nov.

urn:1sid:zoobank.org:act:2B117D04-879D-4584-8641-BC5DFB20F002

Figs 5E, 6A-D, 12

\section{Diagnosis}

The female of $C$. lesotho sp. nov. is recognized by the small triangle in the centre of the epigyne and the obliquely positioned spermathecae provided with a retromedian extension and a frontal protuberance.

\section{Etymology}

The specific epithet is a noun in apposition taken from the type locality.
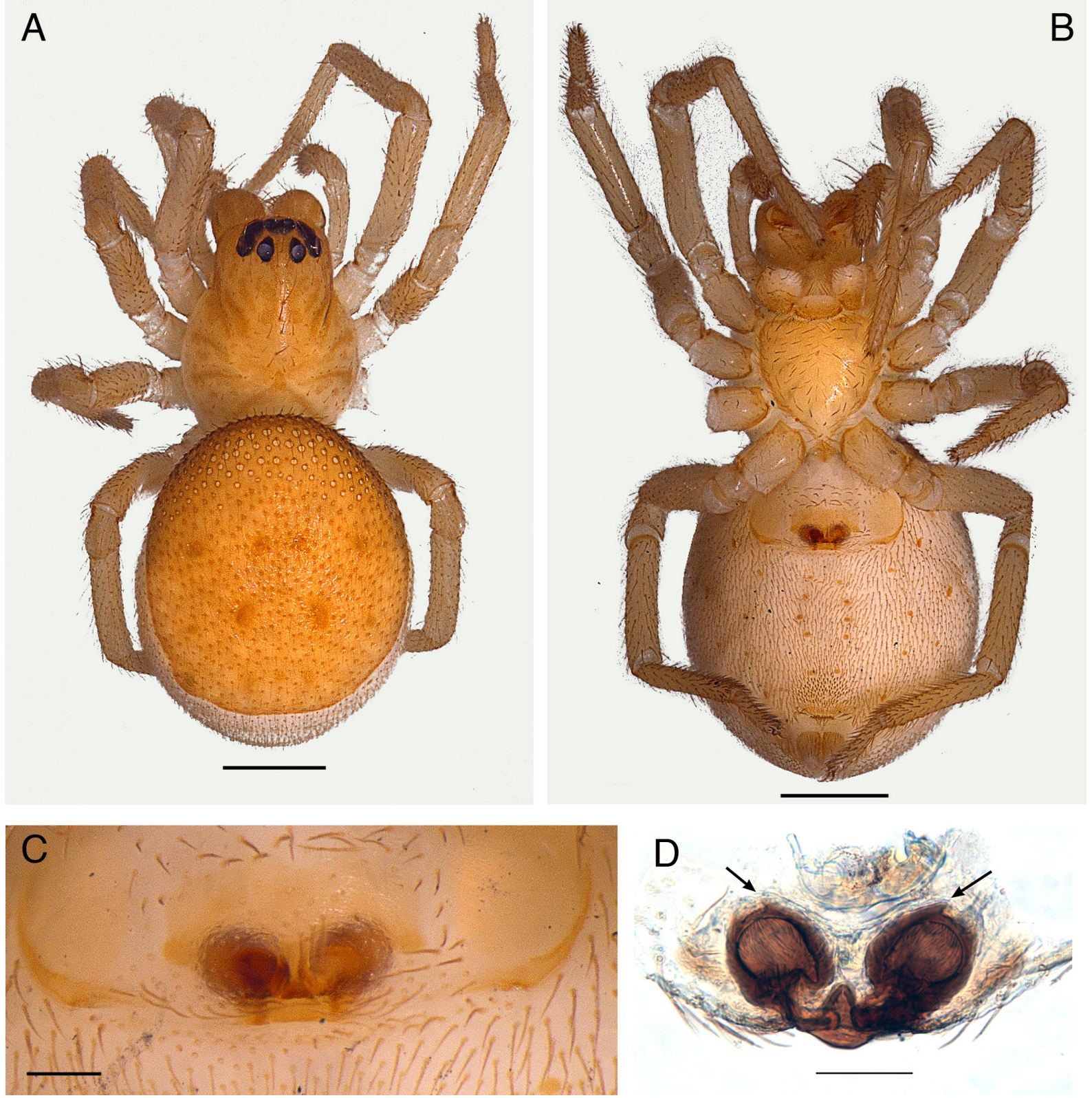

Fig. 6. Chumma lesotho sp. nov., holotype, ․ A. Habitus, dorsal view. B. As preceding, ventral view. C. Epigyne, ventral view. D. Epigyne, cleared, dorsal view. Scale bars: A-B $=0.5 \mathrm{~mm} ; \mathrm{C}-\mathrm{D}=0.2 \mathrm{~mm}$. Arrows indicate anterior protuberance on spermathecae. 


\section{Material examined}

\section{Holotype}

LESOTHO: + , Mohale lodge, Likalaneng, $29^{\circ} 28.425^{\prime} \mathrm{S}, 28^{\circ} 03.412^{\prime} \mathrm{E}, 2233 \mathrm{~m}$ a.s.1., under rock on hillside, 4 Mar. 2003, C. Haddad leg. (MRAC 215897).

\section{Description}

\section{Female}

BODY MEASUREMENTS. TL 3.07, CL 1.23, CW 1.03, CH 0.63.

CARAPACE. Pale yellow, with darker pale brown striae and pattern in cephalic area; chelicerae, legs and sternum pale yellow (Fig. 6A-B).

ABDOMEN. With subcircular pale brown scutum, anterior part with spiniform setae in sockets in front of pale circles becoming smaller backwards, absent from one third of scutum length.

Eyes. AME: 0.20; ALE: 0.33; AME-AME: 0.07; AME-ALE: 0.07; PME: 0.27; PLE: 0.30; PME-PME: 0.27; PME-PLE: 0.13. Clypeus 0.17 or 0.52 times width of ALE.

Sternum. Length 1.73 , width: 1.73 , as long as wide.

Legs. Tarsi slightly curved. Fe I with one dorsal and one prolateral spine, Fe II with one dorsal spine.

\section{LEG MEASUREMENTS.}

\begin{tabular}{ccccccc}
\hline & $\mathbf{F e}$ & $\mathbf{P}$ & $\mathbf{T i}$ & $\mathbf{M t}$ & $\mathbf{t}$ & Total \\
\hline I & 0.93 & 0.37 & 0.87 & 0.67 & 0.50 & 3.33 \\
II & 0.83 & 0.30 & 0.63 & 0.60 & 0.43 & 2.80 \\
III & 0.70 & 0.37 & 0.47 & 0.50 & 0.33 & 2.37 \\
IV & 1.00 & 0.43 & 0.77 & 0.83 & 0.40 & 3.43 \\
\hline
\end{tabular}

EPIGYNE (Figs 5E, 6C-D). Small rectangular depression, preceded by a narrow ridge; spermathecae visible in transparency, subglobular, provided with tapered retro-median extension and anterior protuberance.

\section{Male \\ Unknown.}

\section{Distribution}

Known only from the type locality in central Lesotho (Fig. 12).

Chumma striata sp. nov. urn:1sid:zoobank.org:act:49784BF2-D421-4B7C-B05A-05CE34A69179

Figs $7 \mathrm{~A}-\mathrm{G}, 8 \mathrm{~A}, 12$

\section{Diagnosis}

Females of this species can be distinguished by the characteristics of the epigyne: the spermathecae are globular and devoid of a frontal excrescence whereas in the closely related $C$. gastroperforata the spermathecae are laterally concave and provided with a small knob. Males are distinguished by characteristics of the palp: the tibia is shorter and broader than in C. gastroperforata and the teeth on the posterior rim are closer to the extremity (Jocqué 2001: fig. 10d-e). 

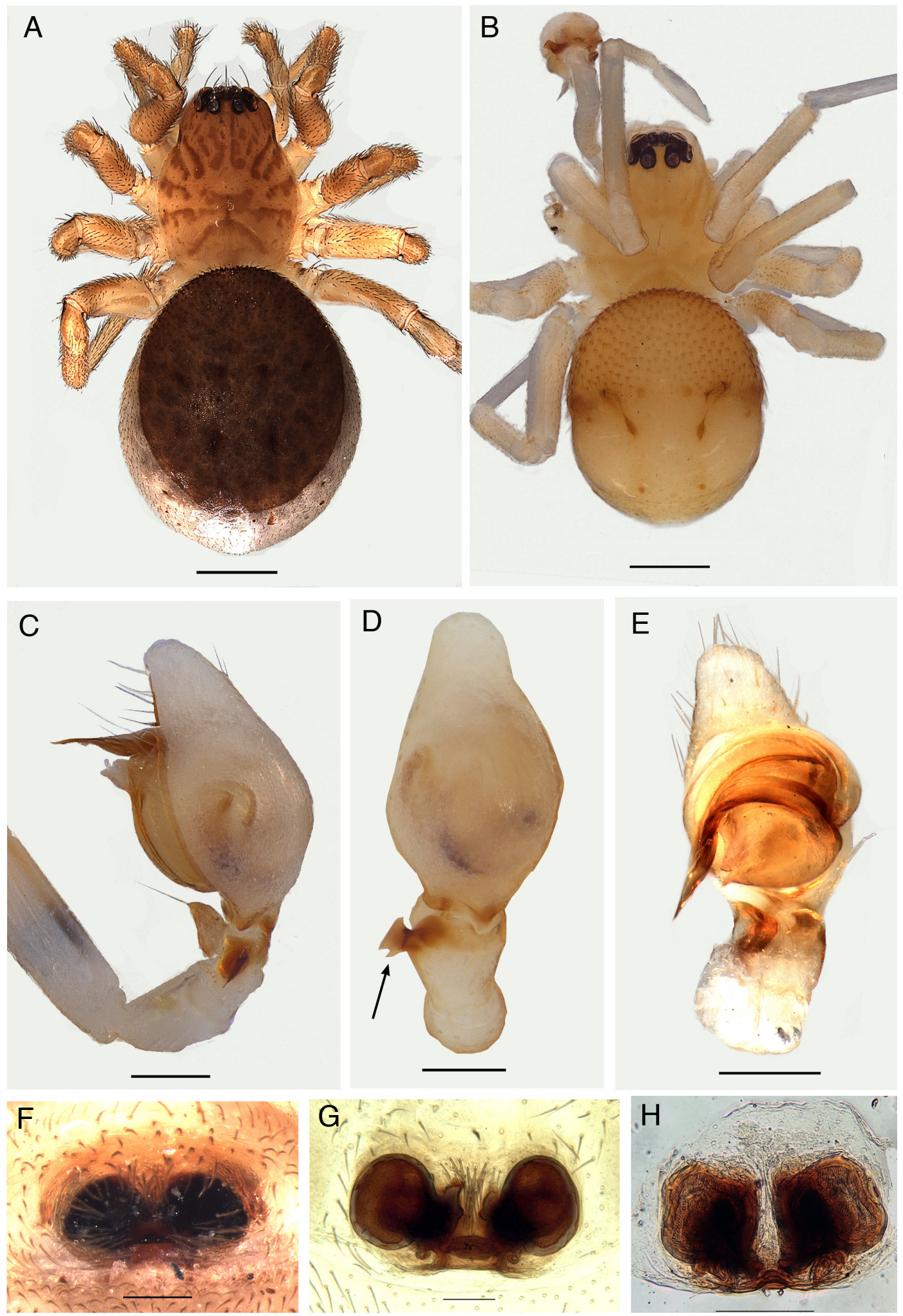

Fig. 7. Chumma striata sp. nov. A, F, G. Holotype, $q$. B, E. $ð$ (MRAC 169642). C, D. $\lesssim$ (MRAC 169733). A. Habitus, dorsal view. B. Habitus, dorsal view. C. Palp, retrolateral view. D. As preceding, dorsal view (arrow indicates posterior spine on RTA). E. As preceding, ventral view. F. Epigyne, ventral view. G. Epigyne, cleared, dorsal view. - H. Chumma gastroperforata Jocqué, 2001, paratype, $q$ (MRAC 131718), epigyne. Scale bars: A-B $=0.5 \mathrm{~mm} ; \mathrm{C}-\mathrm{E}=0.2 \mathrm{~mm}, \mathrm{E}-\mathrm{H}=0.1 \mathrm{~mm}$. 


\section{Etymology}

The specific epithet 'striata', Latin for 'striped', refers to the stripes on the cephalothorax.

\section{Material examined}

\section{Holotype}

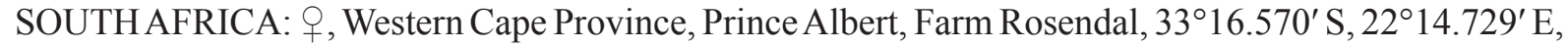
24-26 Sep. 2006, R. Lyle, R. Fourie, V. Swart, J. Saaiman, R. du Preez and D. Van Rensburg leg. (NCA 2008/2868).

\section{Other material}

SOUTH AFRICA: 3 q $q$, same collecting data as for holotype; $1 \hat{\jmath}$, George, Saasveld forestry station, $33^{\circ} 58^{\prime} \mathrm{S}, 22^{\circ} 27^{\prime} \mathrm{E}$, sieved litter, 12 Jan. 1989, R. Jocqué leg. (MRAC 169642); 1 ○, $10 \mathrm{~km}$ E of George,

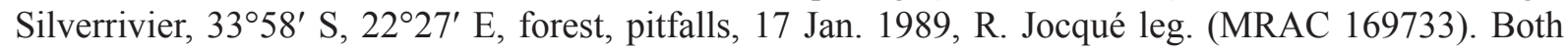
males were described as paratypes of C. gastroperforata in Jocqué (2001).

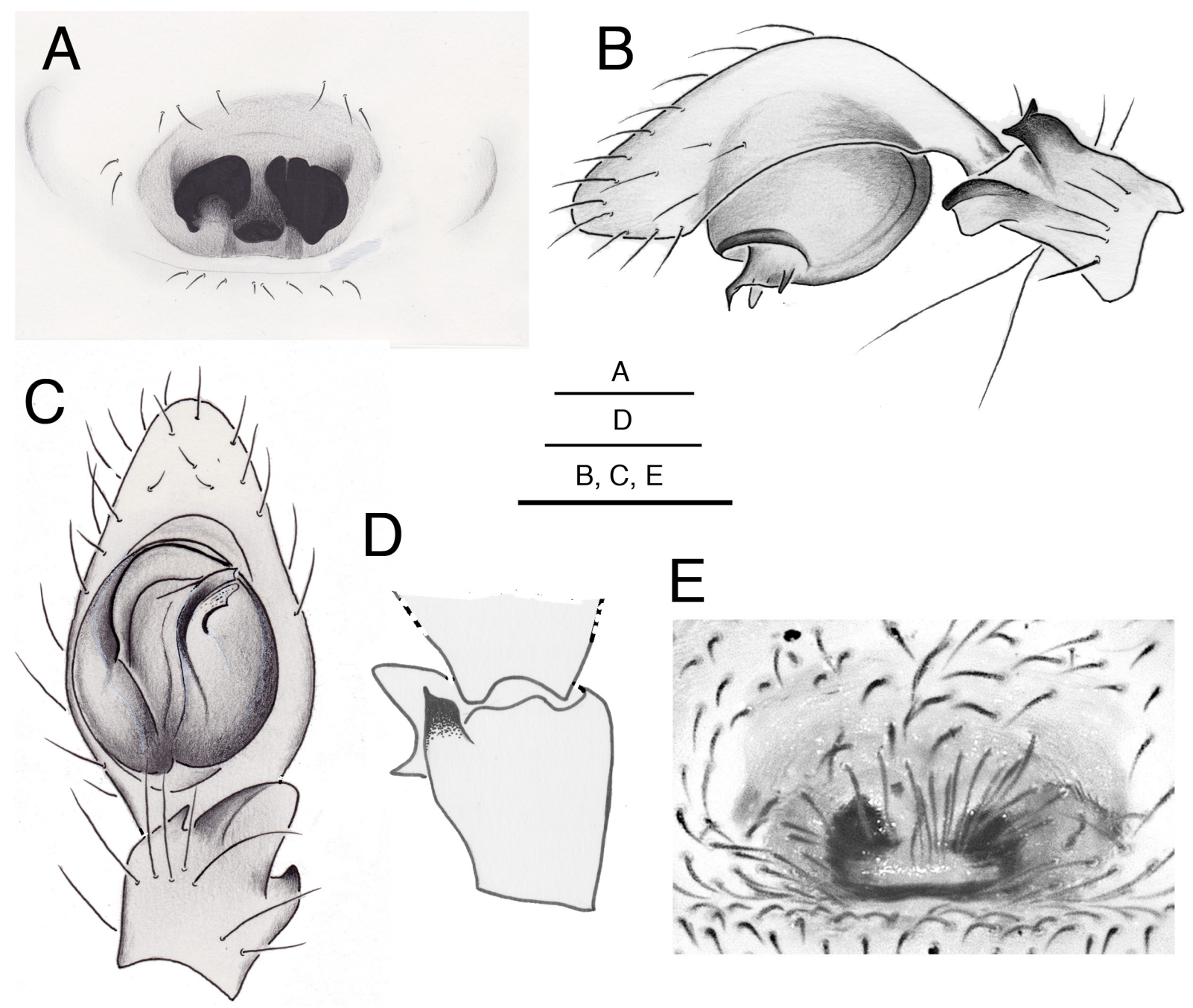

Fig. 8. A. Chumma striata sp. nov., holotype, ${ }$, epigyne, ventral view. - B-E. Chumma subridens sp. nov. B-D. Holotype, ठ․ B. Palp, retrolateral view. C. As preceding, ventral view. D. Palpal tibia, dorsal view. E. Paratype,, , epigyne, ventral view (NCA 2013/4474). Scale bars: $0.2 \mathrm{~mm}$. 


\section{Description}

\section{Female}

Body MEASUREMENTS. TL 2.34, CL 1.28, CW 0.99, CH 0.71.

CARAPACE. Yellow with pattern of medium brown stripes (Fig. 7A); chelicerae and sternum yellow.

ABDOMEN. Grey with medium brown transparent scutum; without pale spots behind sockets of scutum hairs; spinnerets yellow.

Eyes. AME: 0.07; ALE: 0.08; ALE-ALE: 0.02; AME-ALE: 0.03; PME: 0.12: PLE: 0.12; PME-PME: 0.08; PME-PLE: 0.04. Clypeus 0.05 or 1.6 times width of ALE.

Sternum. Shield-shaped, as long as wide: 0.61 .

LEG MEASUREMENTS.

\begin{tabular}{ccccccc}
\hline & $\mathbf{F e}$ & $\mathbf{P}$ & $\mathbf{T i}$ & $\mathbf{M t}$ & $\mathbf{t}$ & Total \\
\hline I & 0,87 & 0,33 & 0,80 & 0,67 & 0,54 & 3,21 \\
II & 0,80 & 0,33 & 0,59 & 0,64 & 0,46 & 2,82 \\
III & 0,66 & 0,30 & 0,49 & 0,54 & 0,30 & 2,28 \\
IV & 0,98 & 0,34 & 0,74 & 0,98 & 0,39 & 3,44 \\
\hline
\end{tabular}

EPIGYNe (Figs 7F-G, 8A). A dark yellow area provided with a tiny rectangular plate near posterior rim, preceded by the spermathecae, visible in transparency as dark brown spots. Vulva with large globular spermathecae devoid of frontal excrescence.

\section{Male}

The male was described by Jocqué (2001) as paratype of Chumma gastroperforata. The male habitus is shown in Fig. 7B, the palp in Fig. 7C-E.

\section{Distribution}

The species is known from the vicinity of George in the Western Cape Province (Fig. 12).

Chumma subridens sp. nov. urn:1sid:zoobank.org:act:238E4AF9-FFC1-4EAE-8DA0-3A14C1057CE7

Figs 8B-E, 9A-G, 12

\section{Diagnosis}

The male of $C$. subridens sp. nov. is recognized by the shape of the double RTA and by the very short truncated embolus and tiny membranous MA; the female is characterized by the epigyne with slightly procurved posterior rim and the oval spermathecae slightly tapered towards the centre.

\section{Etymology}

The specific epithet subridens is derived from the Latin verb 'subridere', to smile, and refers to the pattern of the epigyne. 


\section{Material examined}

\section{Holotype}

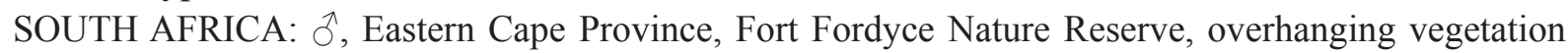
in afromontane forest, $32^{\circ} 41.133^{\prime}$ S, $26^{\circ} 29.875^{\prime}$ E, 1090 m a.s.1., 30 Nov. 2013, C. Haddad leg. (NCA 2013/4474).

\section{Paratypes}

SOUTH AFRICA: $2 q q$, together with holotype; $1 q$, Eastern Cape Province, Fort Fordyce Nature Reserve, leaf litter in afromontane forest, $32^{\circ} 41.226^{\prime} \mathrm{S}, 26^{\circ} 29.622^{\prime} \mathrm{E}, 1015 \mathrm{~m}$ a.s.1., 30 Nov. 2013, C. Haddad and J. Neethling, leg. (NCA 2013/4439).

\section{Other material}

SOUTH AFRICA: 1 q, Western Cape Province, Cape Town, Table Mountain National Park, $33.97^{\circ} \mathrm{S}$, $18.42^{\circ}$ E, 23 May 2008, sifting leaf litter in afrotemperate forest, C. Uys leg. (NCA 2010/1399); 1 ,

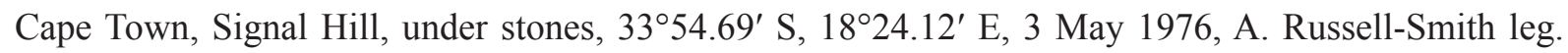
(MRAC 241637).

\section{Description}

\section{Male}

Body MEASUREMENTS. TL 2.50, CL 1.13, CW 0.93, CH 0.43.

CARAPACE. Pale yellow with faint pale brown pattern (Fig. 9A); chelicerae, sternum and legs pale yellow.

ABDomen. With medium brown scutum with dispersed spines, each socket in front of small white spot; four apodemes, poorly impressed; sides and venter white with few apodemes.

Eyes. AME: 0.13; ALE: 0.27; AME-AME: 0.13; AME-ALE: 0.03; PME: 0.20; PLE: 0.27; PME-PME: 0.20; PME-PLE: 0.07. Clypeus 0.13 or 0.48 times width of ALE.

STERNUM. Length 1.60 , width 1.57 , as long as wide.

LEGS. One prolateral spine on femur I.

MEASUREMEnTS.

\begin{tabular}{ccccccc}
\hline & $\mathbf{F e}$ & $\mathbf{P}$ & $\mathbf{T i}$ & $\mathbf{M t}$ & $\mathbf{t}$ & Total \\
\hline I & 1.00 & 0.33 & 0.90 & 0.73 & 0.50 & 3.46 \\
II & 0.83 & 0.33 & 0.70 & 0.56 & 0.53 & 2.95 \\
III & 0.73 & 0.23 & 0.43 & 0.53 & 0.33 & 2.25 \\
IV & 1.07 & 0.33 & 0.80 & 0.96 & 0.43 & 3.59 \\
\hline
\end{tabular}

PaLP (Figs 8B-D, 9C-E). Tibia with two apophyses; dorsal one with two sharp tips; ventral one massive, slightly widened towards indented tip; subtegulum with dark sclerotized rim; embolus short, broad at base, with tiny spines, tapered distally; MA a narrow membranous prong.

\section{Female}

BODY MEASUREMENTS. TL 3.17, CL 1.07, CW 1.07, CH 0.67.

COLOUR AND PATTERNS. Very similar to male, but abdominal scutum smaller, covering only two-thirds of dorsum (Fig. 9B). 


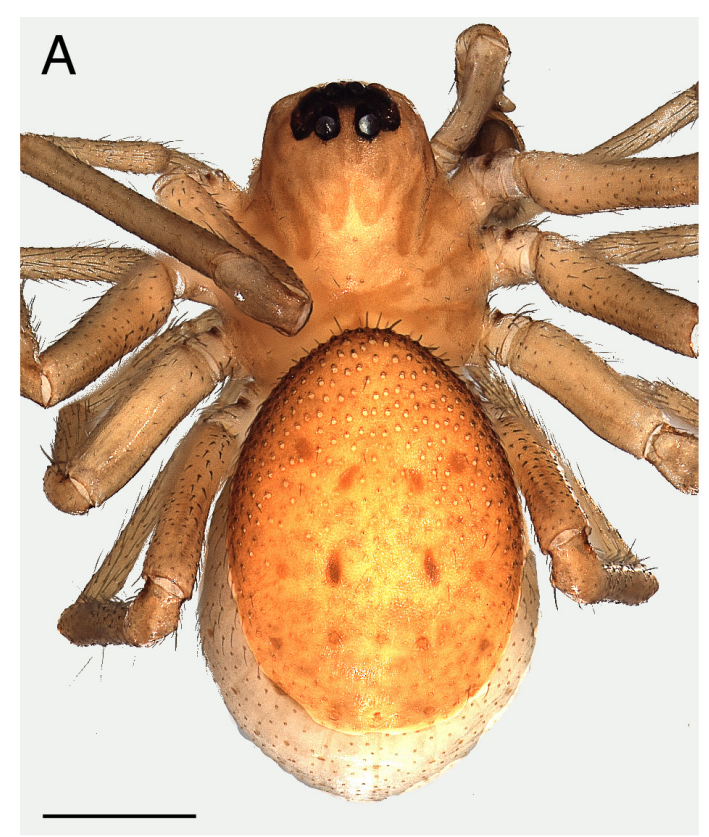

C

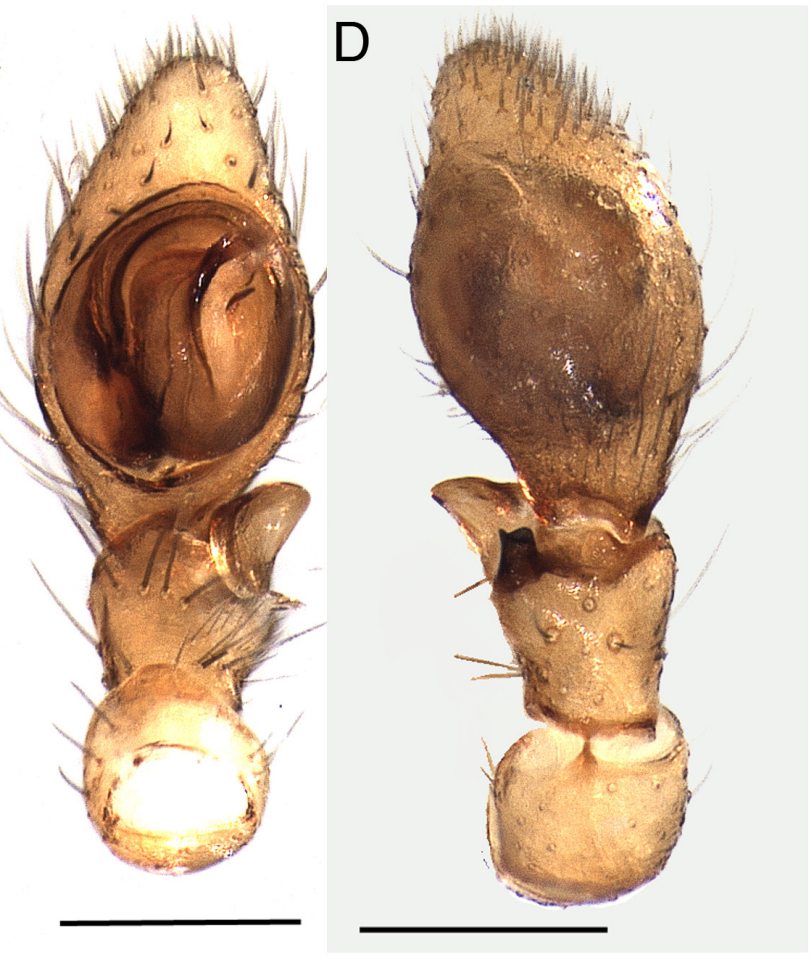

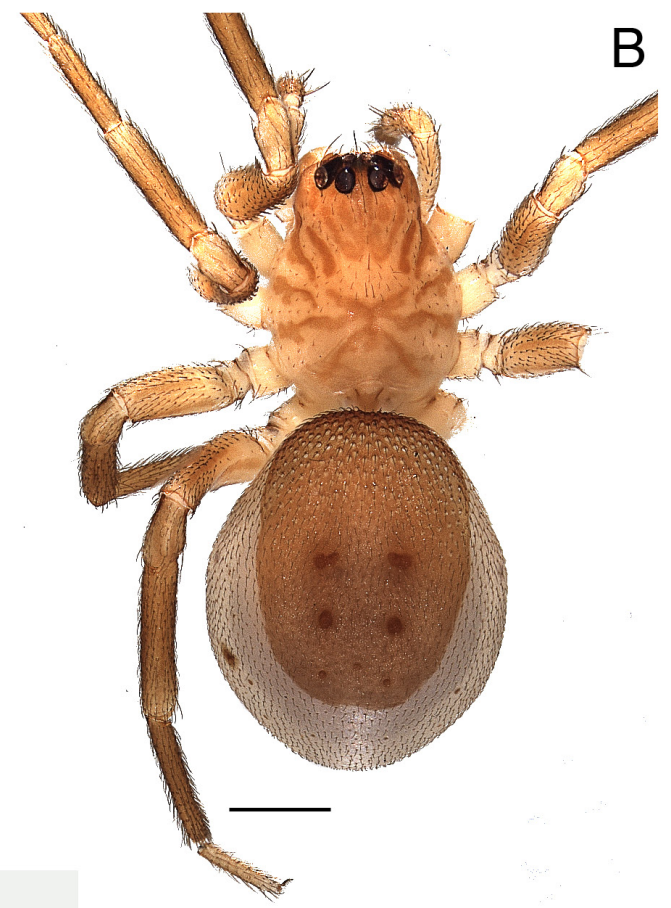
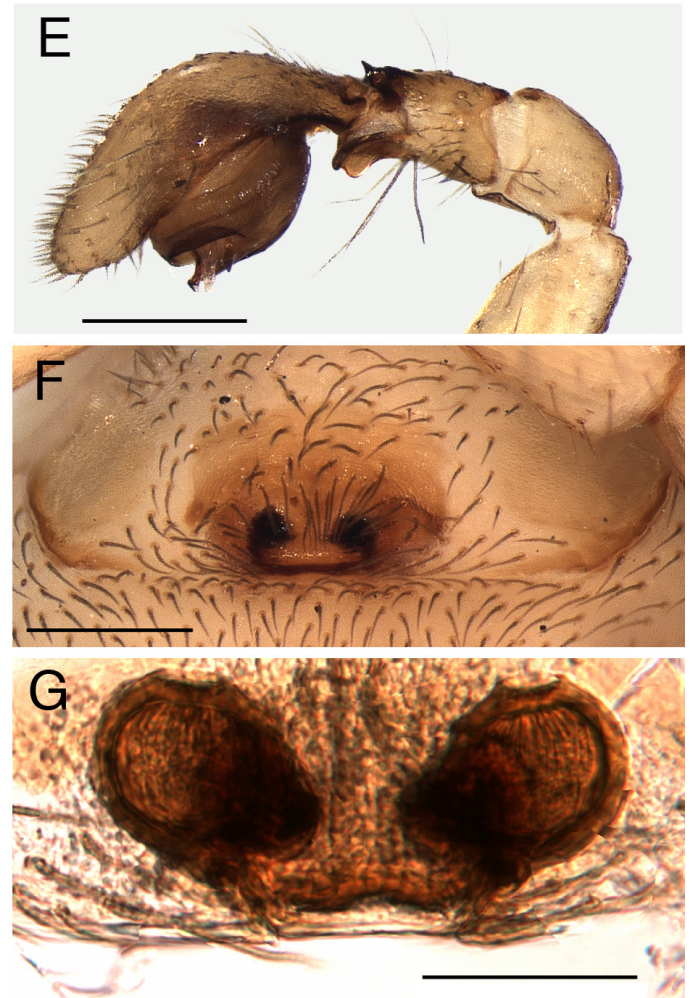

Fig. 9. Chumma subridens sp. nov. A, C-E. Holotype, §̃. B, F-G. Paratype, $ᄋ$ (NCA 2013/4474). A. Habitus, dorsal view. B. Habitus, dorsal view. C. Palp, ventral view. D. As preceding, dorsal view. E. As preceding, retrolateral view. F. Epigyne, ventral view. G. Epigyne, cleared, dorsal view. Scale bars: $\mathrm{A}-\mathrm{B}=0.5 \mathrm{~mm} ; \mathrm{C}-\mathrm{G}=0.2 \mathrm{~mm}$. 
Eyes. AME: 0.17; ALE: 0.30; AME-AME: 0.03; AME-ALE: 0.03; PME: 0.20: PLE: 0.27; PME-PME: 0.20; PME-PLE: 0.07. Clypeus 0.23 or 0.77 times width of ALE.

STERNUM. Length 1.87, width 1.83. Almost as wide as long.

LEG MEASUREMENTS.

\begin{tabular}{ccccccc}
\hline & Fe & $\mathbf{P}$ & Ti & Mt & t & Total \\
\hline I & 1.00 & 0.33 & 0.93 & 0.77 & 0.50 & 3.53 \\
II & 0.93 & 0.33 & 0.67 & 0.63 & 0.43 & 3.00 \\
III & 0.77 & 0.27 & 0.53 & 0.63 & 0.30 & 2.50 \\
IV & 1.07 & 0.37 & 0.77 & 1.03 & 0.47 & 3.70 \\
\hline
\end{tabular}

Epigyne (Figs 8E, 9F-G). With two small copulatory openings separated by narrow scape, adjacent to epigastric furrow; posterior rim slightly procurved; spermathecae large, oval, slightly tapered towards the centre.

\section{Distribution}

Known from the type locality in the Eastern Cape Province and from the Western Cape Province in the vicinity of Table Mountain in South Africa (Fig. 12). The identity of the latter specimens remains doubtful and they were, therefore, not included as paratypes.

Chumma tsitsikamma sp. nov. urn:1sid:zoobank.org:act:A9071899-EE0D-4AF2-B73A-F3039827CE96

Figs $10 \mathrm{~A}-\mathrm{C}, 11 \mathrm{~A}-\mathrm{E}, 12$

\section{Diagnosis}

Males of C. tsitsikamma sp. nov. are recognized by the dorsal bifid RTA with a sharp spur pointing up and backward, and by the solid embolus pointing down.

\section{Etymology}

The specific epithet is a noun in apposition taken from the type locality.

\section{Material examined}

\section{Holotype}

SOUTH AFRICA: ${ }^{\lambda}$, Eastern Cape Province, Tsitsikamma National Park, $34^{\circ} 00.742^{\prime}$ S, $23^{\circ} 52.282^{\prime}$ E, high moisture coastal forest, 24 Dec. 2011, J.A. Neethling and C. Luwes leg. (NCA 2012/4034).

\section{Paratypes}

SOUTH AFRICA: $3 \widehat{\diamond}$, same collecting data as for holotype (NCA 2015/4659).

\section{Description}

\section{Male}

Body MeAsurements. TL 2.57, CL 1.10, CW 1.00, CH 0.50.

CARApace. Pale yellow with slightly darker striae and cephalic area; chelicerae, legs and sternum pale yellow (Fig. 11A-B). 
AвDомen. With pale brown scutum, strongly narrowed in front; anterior third with supple setae, the frontal rows with sockets in front of pale circle; scutum with four impressed apodemes and two dorsal and two lateral depressions; sides and venter white, with two rows of apodemes.

Eyes. AME: 0.20; ALE: 0.33; AME-AME: 0.07; AME-ALE: 0.03; PME: 0.30; PLE: 0.33; PME-PME: 0.17; PME-PLE: 0.07. Clypeus 0.27 or 0.82 times width of ALE.

STERnUM. Length 1.83, width 1.77, almost as long as wide.

LEGS. Anterior pairs of tarsi fusiform.

LEG MEASUREMENTS.

\begin{tabular}{ccccccc}
\hline & $\mathbf{F e}$ & $\mathbf{P}$ & $\mathbf{T i}$ & $\mathbf{M t}$ & $\mathbf{T}$ & Total \\
\hline I & 1.00 & 0.33 & 0.97 & 0.83 & 0.63 & 3.77 \\
II & 0.90 & 0.33 & 0.73 & 0.70 & 0.50 & 3.17 \\
III & 0.77 & 0.33 & 0.50 & 0.63 & 0.33 & 2.57 \\
IV & 1.17 & 0.37 & 0.87 & 1.07 & 0.53 & 4.00 \\
\hline
\end{tabular}

Palp (Figs 10A-C, 11C-E). Tibia with two apophyses: dorsal one flat, truncated, at its base with sharp spur pointing up and backward; ventral one robust, short with concave ventral side; tegulum with short retrolateral and ventral protrusions; embolus solid, twisted, sharp prong, pointing ventrad.

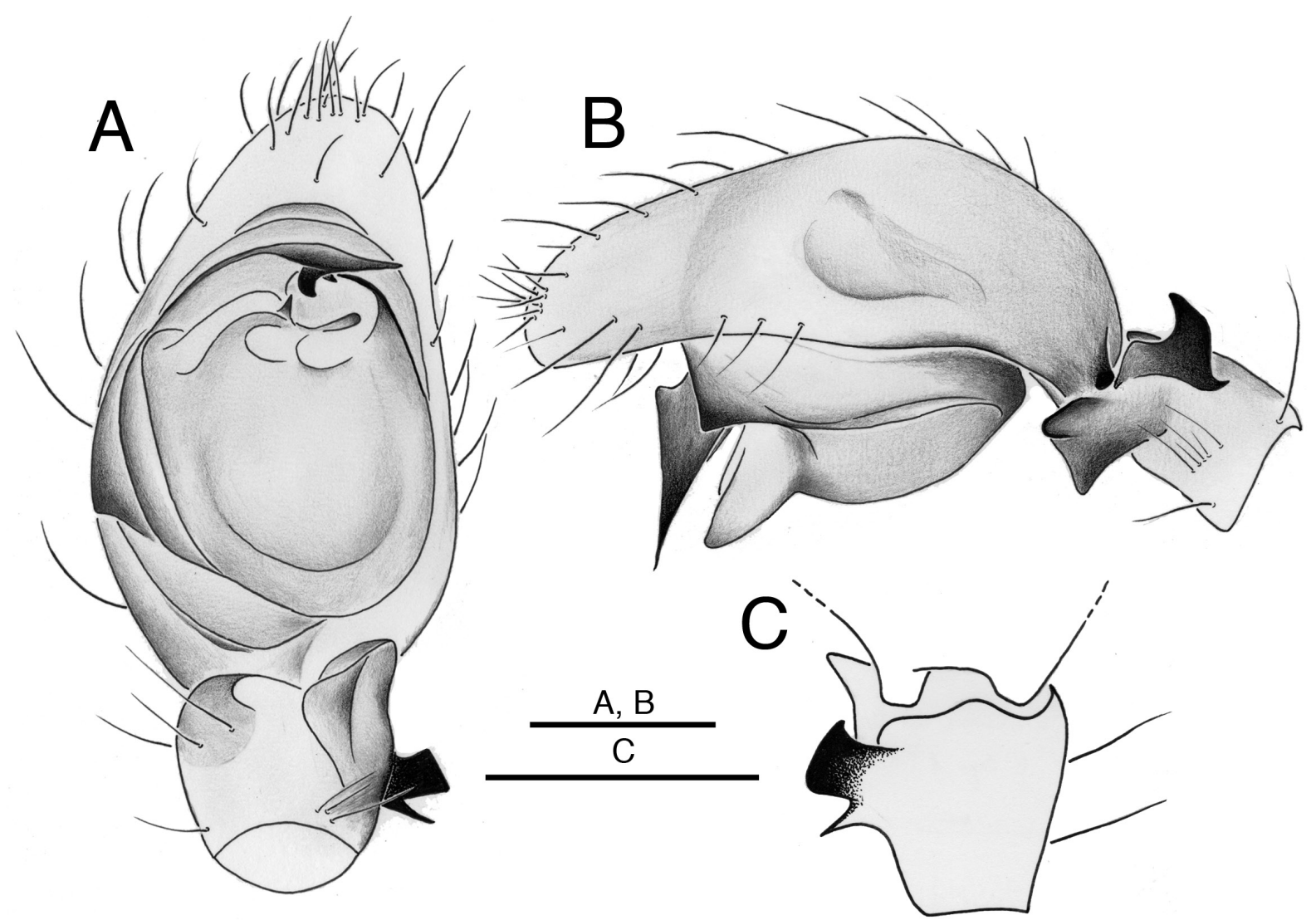

Fig. 10. Chumma tsitsikamma sp. nov., holotype, ô A. Palp, ventral view. B. As preceding, retrolateral view. C. Palpal tibia, dorsal view. Scale bars: $0.2 \mathrm{~mm}$. 


\section{Female}

\section{Unknown.}

\section{Note}

It is not impossible that the females here described as $C$. bicolor sp. nov. belong to the same species. The difference in habitus and mainly the absence of black patches in C. tsitsikamma sp. nov. made us decide to keep them apart.
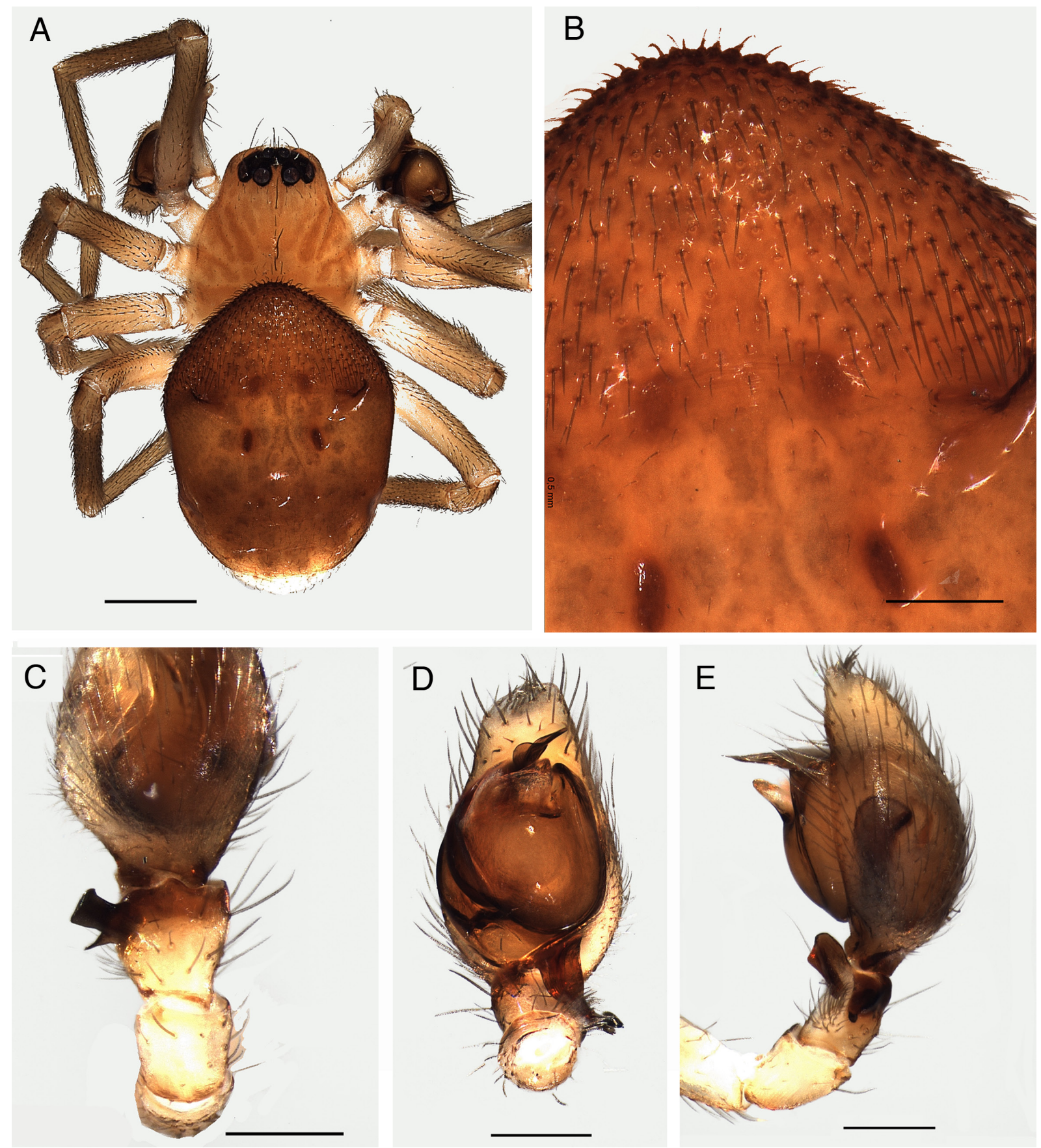

Fig. 11. Chumma tsitsikamma sp. nov., holotype, $\widehat{\partial}$. A. Habitus, dorsal view. B. Anterior part of abdomen, dorsal view. C. Palp, dorsal view. D. As preceding, ventral view. E. As preceding, retrolateral view. Scale bars: $\mathrm{A}-\mathrm{B}=0.5 \mathrm{~mm}$; $\mathrm{C}-\mathrm{F}=0.2 \mathrm{~mm}$. 


\section{Distribution}

Known from the Tsitsikamma National Park in the Eastern Cape Province in South Africa (Fig. 12).

\section{Discussion}

It is possible that the genus Chumma contains two species groups or deserves to be split into two genera. An obvious synapomorphy of one of the genera would be the male with abdominal depressions as in C. gastroperforata, but an unpublished morphological analysis did not result in two sister groups with these males.

The fact that the two initial species of Chumma were described in their own family (Jocqué 2001), reflects the problem with their systematic position from the beginning. Initially, the family was considered as being close to the Zodariidae (Jocqué 2001) but later studies, mainly based on molecular analyses, showed that it is sister to Chresiona Simon, 1903, part of the Macrobuninae (Miller et al. 2010; Dimitrov et al. 2017; Wheeler et al. 2017). This subfamily was considered part of the Amaurobiidae for a long time, but according to the studies of Miller et al. (2010), Dimitrov et al. (2017) and Wheeler et al. (2017) it should deserve family status. It might, therefore, be questioned whether the name Chummidae Jocqué, 2001 is still valid in view of its recent placement. However, considering the morphological differences between Chumma and the other genera in the clade (Chresiona) it is most likely that the species of Chumma will deserve subfamily rank (Chumminae) as sister of the other species in the family (Macrobuninae Lehtinen, 1967) (Dimitrov et al. 2017). In accordance with the rule 35.5 concerning "Precedence for names in use at higher rank" in the International Code of Zoological Nomenclature (2012), Chummidae will then remain valid since it was used as family name before Macrobunidae.

The distribution of the genus is remarkable: it is apparently restricted to the temperate climate zone in the southern part of South Africa, but occurs not only in the particular habitats that are typical for that zone

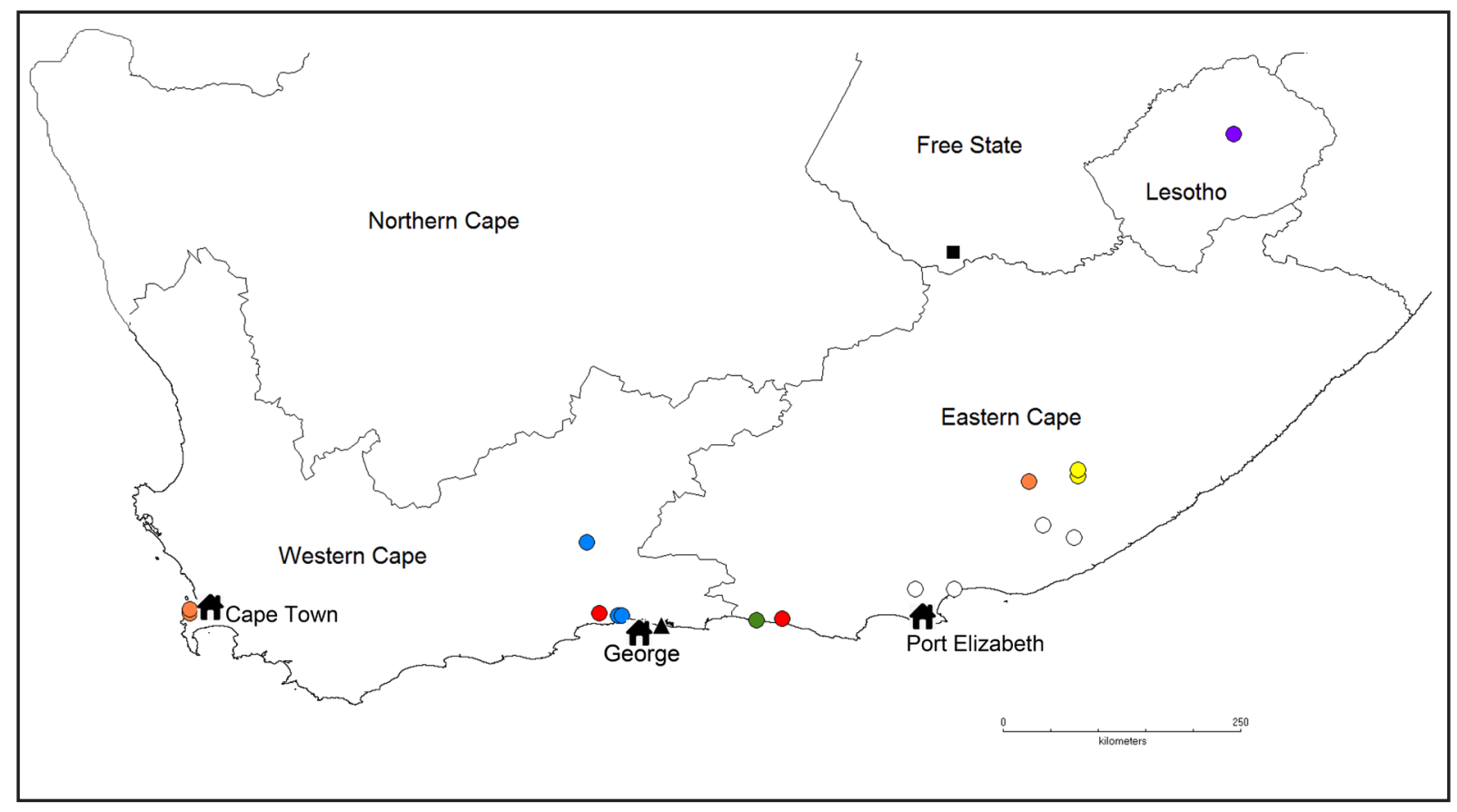

Fig. 12. Distribution map of Chumma spp.: C. bicolor sp. nov. ( $\mathbf{\Delta}) ;$ C. foliata sp. nov. (०); C. gastroperforata Jocqué, 2001 (•); C. inquieta Jocqué, 2001 (०); C. interfluvialis sp. nov. (®);

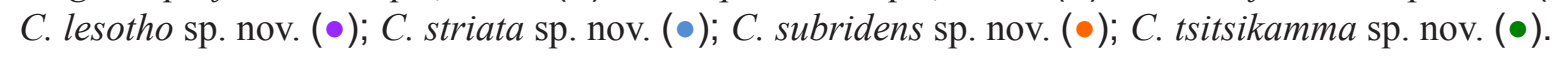


like fynbos or temperate forest, but also in grassland, montane forest and coastal shrub. Representatives of the genus now also have a large altitudinal range from sea level to more than $2200 \mathrm{~m}$ a.s.l. Most species are found in the litter layer or near the ground, but $C$. bicolor sp. nov. was found by beating large shrubs. The species appear to have very small distribution areas, except $C$. subridens sp. nov., which was found from the Eastern Cape Province to Signal Hill at the far western end of the Western Cape Province. Unfortunately, the species appear to be rather rare and most species are found in very few localities with a small number of specimens. Thus, it is difficult to specify the preferred habitat of the species. The exceptionally large distribution of C. subridens sp. nov. is, therefore, difficult to explain. It is possible that it occupies a particular habitat, but the information on the conditions in which the specimens were found is not sufficiently detailed to allow such an explanation.

\section{Acknowledgments}

We are indebted to Charles Haddad for his dedicated efforts to collect representatives of Chumma, and to Ansie Dippenaar-Schoeman, Robin Lyle and Petro Marais for the loans for this study. We are grateful to Charles Griswold who tried in vain to organize a loan of Chumma in American collections. We thank Alain Reygel for the excellent drawings. Ansie Dippenaar-Schoeman and an anonymous referee made useful remarks to the submission.

\section{References}

Bond J.E., Hendrixson B.E., Hamilton C.A. \& Hedin M. 2012. A reconsideration of the classification of the spider infraorder Mygalomorphae (Arachnida: Araneae) based on three nuclear genes and morphology. PLoS One 7 (6): e38753. https://doi.org/10.1371/journal.pone.0038753

Dimitrov D., Benavides Silva L.R., Arnedo M.A., Giribet G., Griswold C.E., Scharff N. \& Hormiga G. 2017. Rounding up the usual suspects: a standard target-gene approach for resolving the interfamilial phylogenetic relationships of ecribellate orb-weaving spiders with a new family-rank classification (Araneae, Araneoidea). Cladistics 33 (3): 221-250. https://doi.org/10.1111/cla.12165

Griswold C.E., Audisio T. \& Ledford J.M. 2012. An extraordinary new family of spiders from caves in the Pacific Northwest (Araneae, Trogloraptoridae, new family). ZooKeys 215: 77-102.

https://doi.org/10.3897/zookeys.215.3547

International Commission on Zoological Nomenclature. 2012. International Code of Zoological Nomenclature. $4^{\text {th }}$ Edition. International Trust for Zoological Nomenclature, London.

Jocqué R. 2001. Chummidae, a new spider family (Arachnida, Araneae) from South Africa. Journal of Zoology 254: 481-493. https://doi.org/10.1017/S095283690100098X

Jocqué R. \& Dippenaar-Schoeman A.S. 2007. Spider Families of the World. Royal Museum for Central Africa, Tervuren. Available from

http://www.africamuseum.be/museum/research/publications/rmca/online/spiders_of_the_world.pdf [accessed 19 Feb. 2018].

Miller J.A., Carmichael A., Ramírez M.J., Spagna J.C., Haddad C.R., Řezáč M., Johannesen J., Král J., Wang X.P. \& Griswold C.E. 2010. Phylogeny of entelegyne spiders: affinities of the family Penestomidae (NEW RANK), generic phylogeny of Eresidae, and asymmetric rates of change in spinning organ evolution (Araneae, Araneoidea, Entelegynae). Molecular Phylogenetics and Evolution 55: 786-804. https://doi.org/10.1016/j.ympev.2010.02.021

Polotow D., Carmichael A. \& Griswold C.E. 2015. Total evidence analysis of the phylogenetic relationships of Lycosoidea spiders (Araneae, Entelegynae). Invertebrate Systematics 29: 124-163. https://doi.org/10.1071/IS14041 
Wheeler W.H., Coddington J.A., Crowley L.M., Dimitrov D., Goloboff P.A., Griswold C.E., Hormiga G., Prendini L., Ramírez M.J., Sierwald P., Almeida-Silva L.M., Álvarez-Padilla F., Arnedo M.A., Benavides Silva L.R., Benjamin S.P., Bond J.E., Grismado C.J., Hasan E., Hedin M., Izquierdo M.A., Labarque F.M., Ledford J., Lopardo L., Maddison W.P., Miller J.A., Piacentini L.N., Platnick N.I., Polotow D., Silva-Dávila D., Scharff N., Szüts T., Ubick D., Vink C.J., Wood H.M. \& Zhang J.X. 2017. The spider tree of life: phylogeny of Araneae based on target-gene analyses from an extensive taxon sampling. Cladistics 33 (6): 574-616. https://doi.org/10.1111/cla.12182

Manuscript received: 8 July 2017

Manuscript accepted: 11 September 2017

Published on: 13 March 2018

Topic editor: Koen Martens

Desk editor: Kristiaan Hoedemakers

Printed versions of all papers are also deposited in the libraries of the institutes that are members of the EJT consortium: Muséum national d'Histoire naturelle, Paris, France; Botanic Garden Meise, Belgium; Royal Museum for Central Africa, Tervuren, Belgium; Natural History Museum, London, United Kingdom; Royal Belgian Institute of Natural Sciences, Brussels, Belgium; Natural History Museum of Denmark, Copenhagen, Denmark; Naturalis Biodiversity Center, Leiden, the Netherlands; Museo Nacional de Ciencias Naturales-CSIC, Madrid, Spain; Real Jardín Botánico de Madrid CSIC, Spain. 